УДК 340

DOI https:// doi.org/10.32837/yuv.v0i2.1737

Д. Брага,

аспірант кафедри адвокатури

Національного юридичного університету імені Ярослава Мудрого

\title{
СКАСУВАННЯ «АДВОКАТСЬКОЇ МОНОПОЛІЇ» НА ПРЕДСТАВНИЦТВО ОСОБИ В СУДІ: ДО АКТУАЛЬНОСТІ ПИТАННЯ
}

Забезпечення прав і законних інтересів фізичних та юридичних осіб $€$ невід'ємною рисою громадянського суспільства, правової демократичної держави. Шляхи вказаного забезпечення $€$ різними, проте основною $є$ можливість особи самостійно або за допомогою професійних фахівців захистити себе, відстоюючи свої правові позиції, відновлюючи порушені права. Ст. 131-2 Конституції України регламентує: «Виключно адвокат здійснює представництво іншої особи в суді, а також захист від кримінального обвинувачення» [1]. Право на правничу допомогу являє собою невід’ємну і невідчужувану можливість отримувати в установленому законом порядку професійну допомогу з питань правового характеру. Надання правничої допомоги є гарантією доступу до правосуддя, що становить основний елемент кожної правової держави. Разом із тим якщо участь адвоката у кримінальному процесі або під час розгляду справи щодо осіб, які притягуються до адміністративної відповідальності, не викликає дискусій, то у цивільному, господарському або адміністративному судочинстві участь професійного адвоката викликає жваві дискусії.

На підставі аналізу спірних точок зору науковців та практичних працівників, а також аналізу чинного процесуального законодавства, нормативної бази, що регулює адвокатську діяльність, завдання статті - сформулювати аргументи проти скасування «адвокатської монополї̈.
Проблеми визначення ролі та місця адвокатури в механізмі здійснення правосуддя були предметом досліджень як низки науковців, так і практиків. Серед учених, які вивчали окремі аспекти цієі проблеми, зокрема «адвокатську монополію» на теренах України, слід відзначити: Н. Березу, Т. Вільчик, В. Гвоздія, О. Дроздова, В. Заборовського, О. Куликова, В. Мацко, О. Овсяннікову та ін.

Слід зауважити, що вказані науковці та дослідники грунтовно вивчали поставлені перед ними питання участі адвокатури як представників особи у суді, проте у зв'язку з останніми змінами у законодавстві окремої правової оцінки потребує аспект доцільності збереження «адвокатської монополії на представництво особи у судах, ураховуючи позиції суддів-конституціоналістів, учених-дослідників та юристів-практиків.

Так звана «адвокатська монополія» в Україні була запроваджена конституційною реформою 2016 р. Згідно із внесеними змінами до Конституції України від 30 вересня 2016 р., регламентувалося, що: 1) представництво відповідно до пункту 3 частини першої статті 131-1 та статті 131-2 цієї Конституції виключно прокурорами або адвокатами у Верховному Суді та судах касаційної інстанції здійснюється з 1 січня 2017 р.; у судах апеляційної інстанції - 31 січня 2018 р.; у судах першої інстанції - 31 січня 2019 р.; 2) представництво органів державної влади та органів місцевого самоврядування в судах виключно прокурорами 
або адвокатами здійснюється 31 січня 2020 p. [1].

Після цього нові редакції процесуальних кодексів доповнили положення, регламентовані Основним Законом щодо представництва адвоката у судах [2]. Так, ч. 2 ст. 15 Цивільного процесуального кодексу України (далі - ЦПК України) встановлено, що «представництво у суді як вид правничої допомоги здійснюється виключно адвокатом (професійна правнича допомога), крім випадків, установлених законом». До того ж, відповідно до ст. 60 ЦПК України, ст. 58 Господарського процесуального кодексу України (далі - ГПК України), ст. 57 Кодексу адміністративного судочинства України (далі КАС України), «представником у суді може бути адвокат або законний представник». Під час розгляду спорів, що виникають із трудових відносин, а також справ у малозначних спорах (малозначні справи), представником може бути особа, яка досягла вісімнадцяти років, має процесуальну дієздатність, за винятком осіб, визначених у ст. 61 ЦПК України, ст. 59 ГПК України [3; 4]. У справах незначної складності й в інших випадках, визначених КАC України, представником може бути фізична особа, яка, відповідно до ч. 2 ст. 43 цього Кодексу, має адміністративну процесуальну дієздатність, за винятком осіб, визначених у ст. 58 КАС України [5].

Необхідно зазначити, що під «представництвом» Закон України «Про адвокатуру та адвокатську діяльність» розуміє «вид адвокатської діяльності, що полягає у забезпеченні реалізації прав і обов'язків клієнта у цивільному, господарському, адміністративному та конституційному судочинстві, в інших державних органах, перед фізичними та юридичними особами, прав і обов'язків потерпілого під час розгляду справ про адміністративні правопорушення, а також прав і обов'язків потерпілого, цивільного позивача, цивільного відповідача у кримінальному провадженні» [6].
Разом із тим «адвокатську монополію» так і не було запроваджено, оскільки 29 грудня 2019 р. набув чинності Закон України від 18 грудня 2019 р. № 390-IX, яким внесено зміни до ЦПК України, ГПК України та КАС України щодо розширення можливостей самопредставництва в суді органів державної влади, органів влади Автономної Республіки Крим, органів місцевого самоврядування, інших юридичних осіб незалежно від порядку їх створення [7]. Таким чином, четвертий етап тієї самої «монополізації», зокрема представництво органів державної влади та органів місцевого самоврядування в судах виключно прокурорами або адвокатами здійснюється 31 січня 2020 р., так і не настав.

Загалом «руйнування» конституційної реформи 2016 р. розпочалося 28.08.2019, коли Президент України подав законопроєкт до Верховної Ради України про внесення змін до Конституції України щодо скасування «адвокатської монополії (далі - законопроєкт № 1013). Верховною Радою України 03.09.2019 було направлено законопро$€$ єт на висновок Конституційного Суду щодо відповідності законопроєкту вимогам статей 157 і 158 Конституції України [8]. Конституційний Суд України (далі - КСУ), зауваживши, що зазначений законопроєкт не передбачає скасування чи обмеження прав та свобод людини і громадянина, надав погоджувальний висновок по запропонованому законопроєкту. Так, у Висновку КСУ зі справи № 2-248/2019(5580/19) від 31.10.2019 зазначено: «Поняття «надання професійної правничої допомоги» не тотожне поняттю «представництво особи в суді». Надання професійної правничої допомоги здійснюють адвокати, натомість представництво особи у суді може бути здійснене за вибором особи адвокатом або іншим суб'єктом. Позитивним обов'язком держави $€$ гарантування участі адвоката у наданні професійної правничої допомоги особі з метою забезпечення iii ефективного доступу до правосуддя 
за рахунок коштів держави у випадках, передбачених законом» [9].

Додаткового висвітлення заслуговує окрема думка судді Конституційного Суду України В. Городовенка щодо Висновку: «У ньому (Висновку. Aвт.) бракує мотивації щодо відповідності законопроєкту, зокрема, таким вимогам, за якими Конституція України не може бути змінена, якщо зміни передбачають скасування чи обмеження прав та свобод людини і громадянина». У науковому висновку члена Науково-консультативної ради Конституційного Суду України О. Дроздова наголошено, що скасування положення статті 131-2 Конституції України щодо здійснення виключно адвокатом представництва іншої особи в суді «призведе до істотного звуження змісту права людини на судовий захист (обмеження конституційного права) та, як наслідок, порушення сутності змісту основного права кожного на судовий захист та справедливий суд» [10].

Цікавим $є$ той факт, що КСУ у Висновку зі справи № 1-15/2016 від 20.01.2016 наголошував, що «адвокат має необхідний професійний рівень та можливість забезпечити реалізацію права особи на захист від кримінального обвинувачення та представництво іiі інтересів у суді. Водночас кожна особа $є$ вільною у виборі захисника своїх прав серед адвокатів», коли визначав таким, що відповідає вимогам ст. ст. 157 та 158 Конституції України законопроєкт № 3524 (щодо правосуддя) [11]. Окрім цього, КСУ констатував, що пропонована законопроєктом для доповнення Конституції України стаття 131-2 не передбачає скасування чи обмеження прав і свобод людини і громадянина [11].

Разом із тим у Рішенні від 16.11.2000 № 13-рп / 2000 КСУ визначив вільний вибір захисника як одну 3 конституційних гарантій [12]. У Рішенні КСУ від 30.09.2009 № 23-рп/2009 зроблено наголос на тому, що особа має вільно, без неправомірних обмежень отримувати допомогу 3 юридичних питань в обсязі і формах, яких вона потребує. КСУ зазначив, що гарантування кожному права на правову допомогу в контексті частини другої статті 3, статті 59 Конституції України $(254$ к /96-ВР) покладає на державу відповідні обов'язки щодо забезпечення особи правовою допомогою належного рівня [13]. Отже, держава у такий спосіб бере на себе обов'язок забезпечувати можливість гарантування кожній особі надання професійної правничої допомоги.

У 2016 р., коли зміни до Конституції України щодо правосуддя оцінювалися КСУ на відповідність нормам Основного Закону, суддя-конституціоналіст І.Д. Сліденко окремою думкою зазначив: «Обмежуючи осіб у праві вибору захисника, вказане положення прямо суперечить ч. 1 ст. 59 Конституції України, а отже, ст. ст. 22 та 157 Конституції України, які не допускають звуження змісту та обсягу існуючих прав і свобод» [14].

Таким чином, проводячи ретроспективу судової практики КСУ та аналізуючи окремі думки його суддів, можливо дійти двох висновків: по-перше, рішення КСУ, у тому числі стосовно адвокатської діяльності, залежать від політичної волі чинної на час винесення рішень влади, ставши абсолютно залежним органом; по-друге, питання «адвокатської монополії навіть серед суддівської спільноти сприймається неоднозначно, породжуючи постійні дискусії.

Науковці також висловлюють різні погляди щодо так званої «адвокатської монополії». Так, В. Заборовський зауважує, що держава, гарантувавши на конституційному рівні право на надання правничої допомоги особам, які перебувають у складній (проблемній) правовій ситуаціі, повинна забезпечувати й належні умови його реалізації. Такими умовами є встановлення суттєвих кваліфікаційних та інших вимог до кандидатів на набуття статусу адвоката, а також закріплення особливого професійного та незалежного статусу 
адвоката [15, с. 57]. Так, дійсно, Законом України «Про адвокатуру та адвокатську діяльність» визначається, що «адвокатом може бути фізична особа, яка має повну вищу юридичну освіту, володіє державною мовою, має стаж роботи в галузі права не менше двох років, склала кваліфікаційний іспит, пройшла стажування» [6].

На нашу думку, виходячи із законодавчих приписів щодо правового статусу адвоката, держава гарантує надання професійної правничої допомоги громадянам через високі вимоги до його кандидатури.

M. Шпак приєднується до думки, що виключно адвокатами здійснюється дійсно професійна правнича допомога. У своєму дисертаційному дослідженні науковець доходить висновку, що адвокат, виступаючи учасником цивільних процесуальних правовідносин, надає професійну правничу допомогу на висококваліфікованому рівні, а процесуальне представництво адвокатом у цивільному процесі відображає гарантоване Конституцією України право на таку допомогу [16, с. 15].

Цікавою є думка В. Мацко, який відстоює власну позицію на наглядному прикладі: «Чомусь ніхто під сумнів не ставить існування виключного права лікарів на надання медичної допомоги. Ніхто, тому що ніхто не хоче довірити своє здоров'я та життя шарлатану та сумнівному народному знахарю. Тому що людство подолало більшість смертельних захворювань завдяки науці та дослідженням проблематики лікування тих чи інших захворювань. Інститут професійного захисту прав та свобод громадян має не менше значення для людини. Недаремно видатний адвокат Ф. Плевако зазначив: «За прокурором стоїть закон, а за адвокатом - людина зі своєю долею...» [17].

О. Овсяннікова підтримала конституційну реформу щодо правосуддя 2016 р., зауваживши, що вона відповідає сучасним потребам реформування судової системи, сприяє іï подальшому розвитку в напрямі імплементації європейських стандартів судочинства, забезпечення права на справедливий суд [18, с. 215].

Слушною є думка Т. Вільчик, яка вважає конституційним призначенням інституту адвокатури й основною його функцією надання професійної правничої допомоги, яка у різних сферах судочинства може трансформуватися у функцію захисту або представництва, які розділяти неможливо [19, с. 37]. Так, інститут адвокатури є єдиним професійним інститутом, який може запровадити реалізацію ефективного механізму захисту прав та інтересів у суді.

Повертаючись до законопроєкту № 1013, слід звернути увагу, що він викликав обурення і чимало зауважень із боку представників Національної асоціації адвокатів України (НААУ), які вважають, що «можливість будь-якого громадянина бути представником іншої особи у суді (що пропонується президентським законопроєктом № 1013) $€$ кроком в архаїчне минуле, від якого Україна свого часу позбавилася» [20]. Окрім того, в Асоціації відзначають, що законопроєкт № 1013 ставить під загрозу виконання Україною міжнародних зобов'язань, які вона взяла на себе, змінивши Конституцію України у 2016 р. в частині виняткового права адвокатів на представництво у судах, що було ухвалено Венеціанською комісією. НААУ також застерігає, що спробу зупинити впровадження адвокатської монополії на останньому етапі реалізації цієї конституційної зміни може бути розцінено як відступ від демократичних цінностей та рекомендацій Венеціанської комісії i матиме наслідком погіршення ефективності судового захисту законних прав та інтересів громадян і юридичних осіб. Адже реформа 2016 р. щодо виключного права адвокатів на представництво у судах була результатом консолідованих зусиль законодавчого суспільства, законодавців, міжнародних інституцій і стала одним із найбільш удалих компонентів законодавчих змін у системі правосуддя [20]. 


\section{ЮРИАИЧНИЙ ВІСНИК, 2020/2}

Законопроєкт № 1013 14.01.2020 був попередньо схвалений Верховною Радою України, отримано висновок Комітету з питань правової політики з рекомендаціями остаточно прийняти його як закон. Нині законопроєкт знаходиться на стадії очікування його повторного розгляду ВРУ.

Слід відзначити, що Комітет із питань інтеграції України з Європейським Союзом, розглянувши на своєму засіданні $\quad 02.09 .2019$ законопроєкт № 1013, який було внесено Президентом України, визнав його положення такими, які регулюються національним законодавством країн - членів Європейського Союзу. Окрім цього, Комітет уважає доцільним звернутися до Європейської Комісії за демократію через право, для того щоб отримати висновок про його відповідність європейським цінностям та вимогам [21].

Із цього приводу доцільно зауважити, що виняткове представництво адвокатами інтересів клієнтів у судах діє у більшості європейських країн. А в таких країнах, як Іспанія, Італія та Німеччина, Греція, діє виключно адвокатура на всіх рівнях судового представництва. У таких країнах передбачено модель абсолютної монополії на надання правничих послуг, яка означає, що ніхто крім адвокатів не має права надавати консультаційні послуги і представляти клієнта в суді.

Так, у законодавстві Греції містяться норми, відповідно до яких участь адвоката є обов'язковою в будь-яких цивільних справах за деякими винятками. Згідно зі ст. 39 Кодексу адвокатів Греції, право надавати консультації та роз'яснення з юридичних питань, здійснювати представництво у суді та в інших державних органах, забезпечувати правову підтримку у податкових, адміністративних, тарифних справах належить виключно адвокатам. Інші особи, що надають юридичну допомогу, але не мають звання адвоката, хоча й володіють дипломом юридичного факультету, притягуються до відповідальності за ст. 175 § 2 Кримінального кодексу Греції [22, с. 176].
В Австріі адвокатська монополія поширюється на всі суди і відомства Республіки Австрія й охоплює всі повноваження з представництва сторін як у судах, так і поза ними, з публічних і приватноправових питань [22, с. 179].

У Бельгіï, Литві, Молдові, Норвегії, Нідерландах, Португалії, Чехії представлено модель обмеженої монополії на надання адвокатських послуг. За даною моделлю адвокати мають виключне право на представництво у судах, а надання консультацій із правових питань належить поряд з адвокатами й іншим особам. До ознак моделі обмеженої монополії на надання правових послуг адвокатами належать такі: 1) адвокат не має виняткового права на надання правових послуг; 2) прерогативою адвокатів є лише представництво в судах; 3) поряд з адвокатами й інші особи можуть бути представниками у цивільному процесі та можуть надавати консультації з правових питань; 4) якість правової допомоги залежить від рівня кваліфікації особи, яка надає правові послуги [22, с. 185].

Показовим $є$ те, що в усіх цих країнах є високий рівень захищеності прав і свобод громадян, які завжди можуть розраховувати на об'єктивне вирішення суперечок у суді та на висококваліфіковану правничу допомогу.

Поряд із цим чимало науковців, які підтримують скасування «адвокатської монополії, виокремлюючи серед негативних іiі наслідків такі: на думку Л. Шевелюк, адвокатська монополія заважає укріпленню здорової конкуренції на ринку юридичних послуг [23, с. 191]; О. Куликов спостерігае зниження якості надання адвокатських послуг, адже свідоцтво про право на зайняття адвокатською діяльністю не свідчить про високий рівень компетенції його власника [24].

Схожої думки дотримується Н. Береза, яка наголошує, що введення виключного адвокатського представництва призведе до зростання корупції під час замовлення державними органами послуг адвоката. На думку дослід- 
ниці, «штатні юристи, здійснюючи представництво інтересів державних органів, господарських підприємств тощо, більше орієнтуються у справах відповідної установи. Тому на практиці виникне ситуація, за якої штатні юристи клієнта готуватимуть усі документи, а адвокат у суді лише їх зачитає» [25, с. 16]. Разом із тим, на нашу думку, науковець не врахувала особливостей цивільного або адміністративного судочинства, учасниками якого частіше за все виступають фізичні особи, які не володіють спеціальними знаннями в галузі права, а тому потребують професійної правничої допомоги.

Необхідно також звернути увагу, що особливість правового статусу адвоката як представника у суді цивільної, адміністративної або господарської юрисдикції полягає у тому, що він, окрім прав та обов'язків, які закріплюються за ним відповідним процесуальним законодавством, володіє також комплексом професійних прав, обов'язків і гарантій, які передбачені, зокрема, Законом України «Про адвокатуру та адвокатську діяльність» і Правилами адвокатської етики. Отже, наявність такого професійного складника в процесуальному статусі адвоката, на нашу думку, є тією основною рисою, що відрізняє його від інших осіб, які можуть бути представниками в суді.

Таким чином, оскільки адвокатура $€$ необхідним елементом демократичної, правової держави, інститут адвокатури відіграє важливу роль у реалізації принципу верховенства права, конституційних прав на судовий захист, на професійну правничу допомогу, а представництво адвокатом іншої особи в суді як різновид правничої допомоги є ефективним інструментом захисту вказаних цінностей. На нашу думку, цей інститут $є$ єдиним професійним інститутом, який може запровадити реалізацію ефективного механізму захисту прав та інтересів у суді. Держава гарантує надання професійної правничої допомоги громадянам через високі вимоги до кандидатури адвоката.
Разом із тим, ліквідація монополізації адвокатури відкриває доступ на ринок правничих послуг юристів без відповідного свідоцтва про право на зайняття адвокатською діяльністю, що, безумовно, вплине на якість правничих послуг громадянам.

Незважаючи на плюралізм наукових позицій та позицій КСУ щодо діяльності адвоката як представника особи у суді, ми твердо переконані, що скасування «адвокатської монополії - це поворот назад від проєвропейського вектору нашої держави, оскільки, як показує практика передових країн Євросоюзу, зокрема Німеччини, Італії, Бельгії, Норвегії, Нідерландів, монополія адвокатури на представництво у суді позитивно сприяє професійному правничому захисту клієнтів та їхніх інтересів, а високий рівень захищеності прав і свобод громадян репрезентує належний рівень розвитку громадянського демократичного суспільства, до якого тяжіє Україна.

На підставі вищевикладеного можна дійти висновку про правову та соціально-економічну недоцільність конституційних змін у частині адвокатської монополіі, оскільки відсутній баланс між зацікавленими цілями та наслідками такої монополії.

У статті розкривається питання доцільності скасування так званої «адвокатської монополії» на представництво особи у суді. Сьогодні участь адвоката як захисника у кримінальному процесі не викликає жодних заперечень, проте виключне право представництва особи у судах цивільної, господарської, адміністративної юрисдикції адвокатом спонукае до жвавих дискусій серед науковиів-процесуалістів та юристів-практиків. Дане питання досліджується через призму аналізу судової практики КСУ, чинного законодавства, наукових позицій «за» та «проти» скасування «адвокатської монополї̈, а також думок практикуючих правників. У статті також розглядається 
зарубіжний досвід регулювання представництва осіб у судах. Зроблено спробу навести переконливі аргументи недоиільності скасування «адвокатської монополї̈» в Україні. Автором доводиться думка про правову та соціально-економічну недоцільність конституиійних змін у частині адвокатської монополї, оскільки відсутній баланс між зациікавленими изілями та наслідками такої монополії. На думку автора, інститут адвокатури $\epsilon$ єәиним професійним інститутом, який може запровадити реалізацію ефективного механізму захисту прав ma інтересів у суді. Держава гарантує надання професійнӧ правничої допомоги громадянам через високі вимоги до кандидатури адвоката. Разом із тим, як зазначає автор, ліквідація монополізації адвокатури відкриває доступ на ринок правничих послуг юристів без відповідного свідоцтва про право на зайняття адвокатською діяльністю, щз, безумовно, вплине на якість правничих послуг громадянам. У статті зазначено, щзо скасування «адвокатської монополї̈» - ие поворот назад від проєвропейського вектору нашої держави, оскільки, як показує практика передових країн Євросоюзу, зокрема Німеччини, Iталї, Бельгї, Норвегї, Нідерландів, монополія адвокатури на представництво у суді позитивно сприяе професійному правничому захисту клієнтів та їніх інтересів, а високий рівень захищеності прав $i$ свобод громадян репрезентує належний рівень розвитку громадянського демократичного суспільства, до якого тяжіє Україна.

Ключові слова: адвокатська монополія, представництво особи, адвокат, професійна правнича допомога.

Braga D. Abolition of "lawyer's monopoly" on representation of a person in court: to the relevance question

The article reveals the expediency of abolishing the so-called "lawyer's monopoly" on the representation of a person in court. Today, the participation of a lawyer as a defense counsel in criminal proceedings does not cause any objections, but the exclusive right to represent a person in courts of civil, commercial, administrative jurisdiction by a lawyer encourages lively discussions among legal scholars and legal practitioners. This issue is investigated through the prism of the analysis of the jurisprudence of the Constitutional Court of Ukraine, current legislation, scientific positions "for" and "against" the abolition of the "lawyer's monopoly", as well as the opinions of practicing lawyers. The article also considers foreign experience in regulating the representation of persons in courts. An attempt was made to present convincing arguments for the inexpediency of abolishing the "lawyer's monopoly" in Ukraine. The author argues about the legal and socioeconomic inexpediency of constitutional changes in the legal monopoly, as there is no balance between the goals and consequences of such a monopoly. According to the author, the Institute of Advocacy is the only professional institution that can implement an effective mechanism to protect the rights and interests in court. The state guarantees the provision of professional legal assistance to citizens due to high requirements for the candidacy of a lawyer. However, as the author notes, the elimination of the monopolization of the legal profession opens access to the market of legal services for lawyers without a certificate of the right to practice law, which will certainly affect the quality of legal services to citizens. The article notes that the abolition of the "lawyer's monopoly" is a turn back from the pro-European vector of our country, because, as the practice of advanced EU countries, including Germany, Italy, Belgium, Norway, the Netherlands, the bar's monopoly on representation in court positively contributes to protection 
of clients and their interests, and a high level of protection of the rights and freedoms of citizens represents the appropriate level of development of a civil democratic society to which Ukraine aspires.

Key words: lawyer monopoly, representation of a person, lawyer, professional legal assistance.

\section{Література}

1. Конституичія України : Закон України від 28.06.1996 № 254к/96-BP. Відомості Верховної Ради України. 1996. № $30 . \mathrm{Cm}$. 141 .

2. Про внесення змін до Господарського процесуального кодексу України, Цивільного процесуального кодексу України, Кодексу адміністративного судочинства Украіни та інших законодавчих актів : Закон України від 03.10.2017 № 2147-VIII. Відомості Верховної Ради. 2017. № 48. Cm. 436.

3. Цивільний процесуальний кодекс Украінни від 18.03.2004 № 1618-IV. URL : http:// zakon3.rada.gov.ua/laws/show/1618-15.

4. Госnодарськuи процесуальний кодекс України від 06.11.1991 № 1798-XII. URL : http://zakon2.rada.gov.ua/laws / show / 1798-12.

5. Кодекс адміністративного судочинства України від 06.07.2005 № 2747-IV. URL : http://zakon3.rada.gov.ua/laws / show/2747-15.

6. Про адвокатуру та адвокатську діяльність : Закон України від 05.07.2012 № 5076-VI. Відомості Верховної Ради України. 2013. № 27. Ст. 282.

7. Про внесення змін до деяких законодавчих актів України щодо розширення можливостей самопредставниитва в суді органів державної влади, органів влади Автономної Республіки Крим, органів місцевого самоврядування, інших юридиних осіб незалежно від порядку їх створення : Закон України від 18.12.2019 № 390-IX. URL : https://zakon.rada.gov.ua/ laws / show/390-20.

8. Проєкт Закону про внесення змін до Конституції України (щодо скасування адвокатської монополії) № 1013 від 29.08.2019. URL : https://w1.c1.rada.gov. ua / pls / zweb2 / webproc4_1?pf3511=66242.

9. Висновок Конституційного Суду України зі справи №2-248/2019(5580/19) від 31.10.2019. URL : http: / / wrw.ccu.gov. ua/dokument/4-v2019.
10. Окрема думка судді Конституційного Суду Украйни Городовенка В.В. стосовно Висновку Конституиійного Суду України у справі за конституційним зверненням Верховної Ради України про надання висновку щодо відповідності законопроєкту про внесення змін до Конституції України (щодо скасування адвокатської монополіі) (реєстр. № 1013) вимогам cтатей 157 i 158 Конституиї України. URL : http://wrw.ccu.gov.ua/sites / default / files /docs/4_v_2019_1.pdf.

11. Висновок Конституиійного Суду України зі справи № 1-15/2016 від 20.01.2016. URL : https://zakon.rada.gov. ua/laws / show / v001v710-16.

12. Рішення Конституційного Суду України у справі за конституиійним зверненням громадянина Солдатова Геннадія Івановича щодо офіційного тлумачення положень статті 59 Конституції України, статті 44 Кримінально-процесуального кодексу України, статей 268, 271 Кодексу України про адміністративні правопорушення (справа про право вільного вибору захисника) від 16.11.2000 № 13-pn/2000. URL : https://zakon.rada.gov.ua/laws / card / v013p710-00.

13. Рішення Конституйійного Суду України у справі за конституційним зверненням громадянина Голованя Ігоря Володимировича щодо офіційного тлумачення положень статті 59 Конституиіі України (справа про право на правову допомогу) від 30.09.2020 № 23-pn/2009. URL : https: / / zakon.rada.gov.ua/laws / card / v023p710-09.

14. Окрема думка судді Конституиійного Суду України Сліденка І.Д. стосовно Висновку Конституційного Суду України у справі за зверненням Верховної Ради України щодо відповідності законопроєкту про внесення змін до Конституиіі України щодо правосуддя вимогам статей 157 i 158 Конституиії України від 27.01.2016. URL: https: / / zakon.rada.gov.ua / lazes / card / nd01d710-16.

15. Заборовський В.В. Місие і роль адвокатури у механізмі здійснення правосуддя в Україні. Конституційно-правові академічні студіï. 2017. Bun. 2. C. 51-60.

16. Шпак М.В. Професійне представництво адвоката у изивільному процесі : автореф. дис. ... канд. юрид. наук. Харків, 2018. $20 \mathrm{c}$

17. Мацко В. Адвокатська монополія maк чи нi? URL : https://unba.org.ua/ publications / print / 4640-advokats-kamonopoliya--tak-chi-ni.html. 


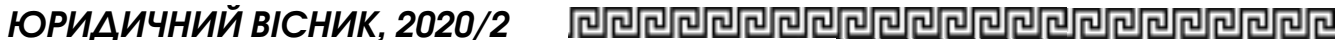

18. Алиева А.В., Овсяннікова О.О. Основні переваги та недоліки впровадження адвокатської монополії в Україні. Молодий вченuй. 2018. № 10(1). С. 213-216.

19. Вільчик Т.Б. Адвокатура України в контексті європейської правової реформи. ХІХ Науково-практична конференція "Адвокатура України: минуле, сучасне та майбутнє». Національний університет «Одеська юридична академія», м. Oдеса. 15 листопада 2019 р. Одеса, 2019. C. 35-41.

20. Офіційна позиція Національної асоціації адвокатів України щзоо відповідності законопроєкту про внесення змін до конституції України (щодо скасування адвокатської монополії) вимогам статей 157 158 Конституцї України. URL : https:// unba.org.ua/assets / uploads / news / advocatura/HAAУ_Bисновок.pdf.
21. Висновок Комітету з питань європейської інтеграиї 02.09.2019. URL http: / / w1.c1.rada.gov.ua/pls / zweb2 / webproc4_1?pf3511=66242.

22. Переверза I.M. Загальнотеоретичні підходи до моделювання адвокатської діяльності : дис. ... канд. юрид. наук. Одеса, 2016. $240 \mathrm{c}$

23. Шевелюк Л. Вплив конституційно-правової реформи в Україні на адвокатуру. Підприємництво, господарство $i$ право. 2017. № 8. С. 189-192.

24. Куликов О. Монополія адвокатури uе погано. НВ Бізнес. 2016. URL : http: // biz.nv.ua/ukr/experts / kulikov/ monopolijaadvokaturi-tse-pogano-180289.html.

25. Береза Н. Монополія адвокатури на здійснення представнищтва в суді. Науковий часопис Національної академії прокуратури України. 2016. № 4(12). С. 10-17. 